\title{
Analyzing Companies Act: A move towards better Governance.
}

\author{
${ }^{1}$ Nishant Sharma*, ${ }^{2}$ Ruchita Dang \\ ${ }^{I}$ Research Scholar Department of Commerce Delhi School of Economics University of Delhi \\ ${ }^{2}$ Motilal Nehru College University of Delhi.
}

\begin{abstract}
With the ever-changing business environment the way in which business firms are supposed to work also changes. No nation can avoid the change in the corporate culture that comes as an external force due to the rapid linkage of various economies \& their corporate entities \& that not only provide ample of opportunities but poses a lot of challenges especially on the governance front. With this changing environment it is in the best interest of the country to keep on incorporating various governance aspects arising in terms of challenges due to changes taking place in corporate arena. This paper is therefore an attempt to understand such the changing corporate laws in India by comparing the two major companies act i.e. Companies Act 1956 \& the recently introduced Companies Act 2013.
\end{abstract}

Keywords: Companies Act 1956, Companies Act 2013, Corporate Governance, Corporate Social Responsibility, Class Action Suit.

\section{Introduction}

The history of corporate laws is ages old in India \& dates back to the time of Chola \& Patliputra who were patrons of trade. The paper attempts to explain the development of corporate laws over time in India \& then to bring about the major differences between the almost 57 years old Companies Act, $1956 \&$ the recently introduced Companies Act, 2013. In order to make the understanding of the paper more clearer the paper has been divided into certain sections wherein the first section that is the present section talks about the concept, meaning \& importance of corporate laws or rather strong and effective corporate laws followed by section II that provides the objectives \& methodology of the paper next is section III that talks of the historical developments in the Indian corporate laws. Section IV is the core section wherein we produce a table showing major points of differences between Companies Act 1956 \& Companies Act 2013. Conclusions \& suggestions are contained in section $\mathrm{V}$ followed by the references in the last section.

Concept of Corporate Laws: Why of it?

Gone are the days when business firms were isolated from the society \& could arrange all the funds for endeavors at their own. Most of the business firms or to say companies, now, require funds to the extent that they cannot arrange from their internal sources \& therefore they ask others to invest in. but the major problem with this " others investing" in your business is the question that whether the amount invested by them is utilized judiciously or not? The answer many a times is "No" this often gives rise to principal-agent conflicts \& to make sure that businesses are not paralyzed for want of funds \& investors are not cheated in any capacity we have various corporate laws such as Indian Contract Act, 1872, Prevention of money laundering Act, 2002, The Sick Industrial Companies Act, 1985, Securities (Amendment) Act, 2004, Companies Act, 2013 etc. A country cannot function or prosper without a strong corporate culture but in order to make sure that the spirit of the corporate culture is not surpassed government has to make various laws \& regulations that not only keep an eye over various corporate but also provide provisions for their better $\&$ effective management $\&$ functioning. India has very recently gone through a radical change in terms of corporate governance $\&$ in terms of its corporate laws with the introduction of Companies Act, 2013 that not only repealed the ages old Companies Act, 1956 but also entails many unheard concepts such as Corporate Social Responsibility, Class Action Suit, One Person Company etc. in order to ensure that good governance prevails the laws \& regulations need to be amended from time to time \& this is what Indian government has done, after the collapse of Satyam it was all the more important to extensively have a relook of the existing Companies Act, 1956.

\section{Objectives}

1. The first $\&$ the foremost objective the paper is to understand the need of having a very comprehensive $\&$ revamped companies act that is to analyze the flaws of companies act $1956 \&$ how these flaws have been addressed.

2. Also, to understand the points where Companies Act 2013 has got an edge over Companies Act 1956.

3. To understand the various developments of Companies Act 2013 \& its role in ensuring better corporate governance in the country. 


\section{Methodology}

The present study is based on the information collected from various secondary sources such as research journals available online, newspaper articles, various website, bare acts \& personal interaction with professionals like Chartered Accountants, Company Secretaries \& others.

\section{Historical Background/Development of Companies Act.}

India has got the independence from British control 1947 but the process of making \& strengthening corporate laws had already begun before that. With the advent of various enactments in England various laws were getting enacted in India too that resulted in acts such as Joint Stock Companies Act, 1850 of India, Joint Stock Companies Act, 1857 of India, Companies Act, 1866 of India, Indian Companies Act, 1913 but the biggest of all procedural act of independent India came into being in 1956 to be called as Companies Act, 1956 which is now replaced by the Companies Act, 2013. A brief historical background of companies act is given below.

Joint Stock Companies Act, 1850

Based on the premises of Joint Stock Companies Act, 1844 of England this act provided for registration of joint stock companies in India \& the three Supreme Courts (Madras, Bombay, and Calcutta) were authorized to give order for registration.

\section{Joint Stock Companies Act, 1857}

The act introduced the concept of limited liability but the benefits were not extended to banking \& insurance companies. The right was afterwards granted through an amendment act.

\section{Indian Companies Act, 1913}

Based on the Companies Act, 1908 Of England the concept of Private Limited Company was materialized. This act went through many amendments.

\section{Companies Act, 1956}

Based on the recommendations of H.C. Bhaba Committee the biggest of all procedural laws in country was enacted on April 1. 1956 divided into XIII parts with 658 sections, 6 tales \& 15 schedules. Companies Act, 1956 repealed all earlier Companies Acts.

Companies Act, 2013

Based on the recommendations of J. J. Irani committee companies bill came into existence in the year 2008 that went through critical evaluations \& after due considerations took the shape of Companies Act, 2013. The bill was passed on $18^{\text {th }}$ of December, 2013 by Lok Sabha \& Rajya Sabha passed the same bill on $8^{\text {th }}$ of august, 2013. The bill then got presidential assent \& was gazetted to become an act. Companies Act, 2013 not only repealed the Companies Act 1956 but also provides for so many unheard concepts. The act comprises of 29 chapters, 470 clauses \& 7 schedules.

Comparison of Companies Act, 1956 \& Companies Act, 2013.

IV. Comparative analysis:

\begin{tabular}{|c|c|c|c|}
\hline Basis & Companies Act 1956 & Companies Act 2013 & Comments/Remarks \\
\hline $\begin{array}{l}\text { 4.Definition } \\
\text { "officer who is in } \\
\text { default" }\end{array}$ & $\begin{array}{l}\text { "Officer who is in default", in } \\
\text { relation to any provision } \\
\text { referred to in section 5, has } \\
\text { the meaning specified in that }\end{array}$ & $\begin{array}{l}\text { "officer who is in default", for } \\
\text { the purpose of any provision in } \\
\text { this Act which enacts that an } \\
\text { officer of the company who is }\end{array}$ & $\begin{array}{l}\text { The scope of officer in default } \\
\text { has been broadened. }\end{array}$ \\
\hline
\end{tabular}

${ }^{1}$ Section 124 of Companies Act, 1956

${ }^{2}$ Section 2 (16) of Companies Act, 2013. 


\begin{tabular}{|c|c|c|c|}
\hline & $\begin{array}{l}\text { section. } \\
\text { Section 5: For the purpose of } \\
\text { any provision in this Act } \\
\text { which enacts that an officer } \\
\text { of the company who is in } \\
\text { default shall be liable to any } \\
\text { punishment or penalty, } \\
\text { whether by way of } \\
\text { imprisonment, fine or } \\
\text { otherwise, the expression } \\
\text { "officer who is in default" } \\
\text { means all the following } \\
\text { officers of the company, } \\
\text { namely : (a) the managing } \\
\text { director or managing } \\
\text { directors ; (b) the whole-time } \\
\text { director or whole-time } \\
\text { directors ; (c) the manager ; } \\
\text { (d) the secretary (e) any } \\
\text { person in accordance with } \\
\text { whose directions or } \\
\text { instructions the Board of } \\
\text { directors of the company is } \\
\text { accustomed to act ; (f) any } \\
\text { person charged by the Board } \\
\text { with the responsibility of } \\
\text { complying with that } \\
\text { provision : Provided that the } \\
\text { person so charged has given } \\
\text { his consent in this behalf to } \\
\text { the Board ; (g) where any } \\
\text { company does not have any } \\
\text { of the officers specified in } \\
\text { clauses (a) to (c), any director } \\
\text { or directors who may be } \\
\text { specified by the Board in this } \\
\text { behalf or where no director is } \\
\text { so specified, all the directors : } \\
\text { Provided that where the } \\
\text { Board exercises any power } \\
\text { under clause (f) or clause (g), } \\
\text { it shall, within thirty days of } \\
\text { the exercise of such powers, } \\
\text { file with the Registrar a } \\
\text { return in the prescribed } \\
\text { form. }{ }^{3} \text { and }\end{array}$ & $\begin{array}{l}\text { in default shall be liable to any } \\
\text { penalty or punishment by way } \\
\text { of imprisonment, fine or } \\
\text { otherwise, means any of the } \\
\text { following officers of a } \\
\text { company, namely:- (i) whole- } \\
\text { time director; (ii) key } \\
\text { managerial personnel; (iii) } \\
\text { where there is no key } \\
\text { managerial personnel, such } \\
\text { director or directors as } \\
\text { specified by the Board in this } \\
\text { behalf and who has or have } \\
\text { given his or their consent in } \\
\text { writing to the Board to such } \\
\text { specification, or all the } \\
\text { directors, if no director is so } \\
\text { specified; (iv) any person who, } \\
\text { under the immediate authority } \\
\text { of the Board or any key } \\
\text { managerial personnel, is } \\
\text { charged with any responsibility } \\
\text { including maintenance, filing } \\
\text { or distribution of accounts or } \\
\text { records, authorizes, actively } \\
\text { participates in, knowingly } \\
\text { permits, or knowingly fails to } \\
\text { take active steps to prevent, any } \\
\text { default; (v) any person in } \\
\text { accordance with whose advice, } \\
\text { directions or instructions the } \\
\text { Board of Directors of the } \\
\text { company is accustomed to act, } \\
\text { other than a person who gives } \\
\text { advice to the Board in a } \\
\text { professional capacity; (vi) } \\
\text { every director, in respect of a } \\
\text { contravention of any of the } \\
\text { provisions of this Act, who is } \\
\text { aware of such contravention by } \\
\text { virtue of the receipt by him of } \\
\text { any proceedings of the Board } \\
\text { or participation in such } \\
\text { proceedings without objecting } \\
\text { to the same, or where such } \\
\text { contravention had taken place } \\
\text { with his consent or connivance; } \\
\text { (vii) in respect of the issue or } \\
\text { transfer of any shares of a } \\
\text { company, the share transfer } \\
\text { agents, registrars and merchant } \\
\text { bankers to the issue or transfer } \\
\text { ond }\end{array}$ & \\
\hline $\begin{array}{l}\text { 5.One person } \\
\text { company }\end{array}$ & $\begin{array}{l}\text { Earlier this concept was not } \\
\text { there in the act. }\end{array}$ & $\begin{array}{l}\text { OPC means a company which } \\
\text { has only one person as a } \\
\text { member. }\end{array}$ & $\begin{array}{l}\text { This will increase the number } \\
\text { of companies. }\end{array}$ \\
\hline $\begin{array}{l}\text { 6.Prohibition on issue } \\
\text { of shares at discount. }\end{array}$ & $\begin{array}{l}\text { Earlier companies have a } \\
\text { power to issue shares at } \\
\text { discount. }\end{array}$ & $\begin{array}{l}\text { Now the companies cannot } \\
\text { issue shares at discount except } \\
\text { sweat equity shares subject to } \\
\text { fulfillment of certain } \\
\text { conditions. }\end{array}$ & $\begin{array}{l}\text { If company contravenes the } \\
\text { provision shall be punishable } \\
\text { with a fine not less than one } \\
\text { lakh rupees which may extend } \\
\text { to five lakh rupees. }\end{array}$ \\
\hline $\begin{array}{l}\text { 7. Power of company } \\
\text { to purchase its own } \\
\text { securities. }\end{array}$ & $\begin{array}{l}\text { Power of company to } \\
\text { purchase its own securities }{ }^{8} \text {. } \\
\text { In case of buy back by board } \\
\text { no further buy back is }\end{array}$ & $\begin{array}{l}\text { Company can purchase its own } \\
\text { shares or other securities out of } \\
\text { free reserves, security premium } \\
\text { account, or the proceeds of any }\end{array}$ & $\begin{array}{l}\text { For the purpose of new act "free } \\
\text { reserves" include security } \\
\text { premium account. }\end{array}$ \\
\hline
\end{tabular}

\footnotetext{
${ }^{3}$ Section 2(35) of the Companies Act, 1956.

${ }^{4}$ Section 2(60) of the Companies Act, 2013.

${ }^{5}$ Section 2(62) of the Companies Act, 2013

${ }^{6}$ Section 79 of the Companies Act, 1956.

${ }^{7}$ Section 53 of the Companies Act, 2013.

${ }^{8}$ Section 77A of the Companies Act. 1956
} 


\begin{tabular}{|c|c|c|c|}
\hline & $\begin{array}{l}\text { permissible within a period of } \\
365 \text { days from the date of } \\
\text { preceding buy back. }\end{array}$ & $\begin{array}{l}\text { shares or other specified } \\
\text { securities }{ }^{9} \text {. Now no buy back is } \\
\text { permissible within a period of } \\
365 \text { days whether approved by } \\
\text { board or shareholders. }\end{array}$ & \\
\hline $\begin{array}{l}\text { 8.Prohibition on } \\
\text { acceptance of deposits } \\
\text { from public }\end{array}$ & $\begin{array}{l}\text { Deposits not to be invited } \\
\text { without } \quad \text { issuing } \\
\text { advertisement. }\end{array}$ & $\begin{array}{l}\text { Prohibition on acceptance of } \\
\text { deposits from public. }{ }^{11}\end{array}$ & $\begin{array}{llr}\text { With regard to "unsecured } \\
\text { deposits" company } & \text { should } \\
\text { quote this } & \text { in } & \text { every } \\
\text { advertisement } & \text { relate r to } \\
\text { invitation or acceptance of } \\
\text { deposits. }\end{array}$ \\
\hline 9.Notice of meeting & $\begin{array}{l}\text { This deals with length of } \\
\text { notice and on the other hand } \\
\text { other section deals with } \\
\text { contents and manner of } \\
\text { service of notice }{ }^{12} \text {. }\end{array}$ & $\begin{array}{l}\text { It explains the procedure of } \\
\text { notice of meeting. }\end{array}$ & $\begin{array}{l}\text { Earlier this was divided in } \\
\text { different sections, but now } \\
\text { everything regarding notice is } \\
\text { merged in one section. }\end{array}$ \\
\hline 10.Minutes of meeting & $\begin{array}{l}\text { It covers all the aspects } \\
\text { minutes of proceedings of } \\
\text { general meetings }{ }^{14} \text {. }\end{array}$ & $\begin{array}{l}\text { It explains the minutes of } \\
\text { proceedings of general } \\
\text { meetings, board meetings, and } \\
\text { any other general meeting and } \\
\text { all the resolutions passed by } \\
\text { postal ballot. }{ }^{15}\end{array}$ & $\begin{array}{l}\text { Corresponds to various sections } \\
\text { now only one single section } \\
\text { deals with the minutes of } \\
\text { meeting. }\end{array}$ \\
\hline $\begin{array}{l}\text { 11. Appointment of } \\
\text { Auditors }\end{array}$ & $\begin{array}{l}\text { It covers the appointment and } \\
\text { remuneration of auditors in } \\
\text { government and other } \\
\text { companies. }\end{array}$ & $\begin{array}{l}\text { It deals with appointment of } \\
\text { auditors. }{ }^{17}\end{array}$ & $\begin{array}{l}\text { The Act } 2013 \text { also provides } \\
\text { for rotation of auditing } \\
\text { partner and his team within } \\
\text { an audit firm. }\end{array}$ \\
\hline $\begin{array}{l}\text { 12. Corporate Social } \\
\text { Responsibility }\end{array}$ & $\begin{array}{l}\text { Earlier this section was not } \\
\text { there. }\end{array}$ & $\begin{array}{l}\text { Every company having net } \\
\text { worth of rupees } 5 \text { hundred } \\
\text { crore or more, or turnover of } \\
\text { rupees one thousand crore or } \\
\text { more or a net profit of rupees } \\
\text { five crore or more during any } \\
\text { financial year shall constitute a } \\
\text { Corporate social responsibility } \\
\text { committee of board consisting } \\
\text { of three or more directors, out } \\
\text { of which at least one director } \\
\text { shall be an independent } \\
\text { director. }{ }^{18}\end{array}$ & $\begin{array}{l}\text { Now, this section is mandatory } \\
\text { for all the companies who come } \\
\text { under the ambit of the provision } \\
\text { of said section. }\end{array}$ \\
\hline 13.Debentures & $\begin{array}{l}\text { Earlier there were different } \\
\text { sections which deals with } \\
\text { debentures, which includes } \\
\text { debenture trust deed, } \\
\text { appointment of debenture } \\
\text { trustees etc }^{19}\end{array}$ & $\begin{array}{l}\text { As per new act company can } \\
\text { issue debentures with an option } \\
\text { to convert them into shares } \\
\text { wholly or partly approved by } \\
\text { special resolution. Now there is } \\
\text { only one section which deals in } \\
\text { debentures. }^{20}\end{array}$ & $\begin{array}{l}\text { Now there is only one section } \\
\text { which deals in debentures. }\end{array}$ \\
\hline 14.Cost Audit & $\begin{array}{l}\text { Cost Audit was allowed in } \\
\text { certain cases. }^{21}\end{array}$ & $\begin{array}{l}\text { Central government after } \\
\text { consultation with regulatory } \\
\text { authority may direct certain } \\
\text { class of companies for cost } \\
\text { audit. }\end{array}$ & $\begin{array}{l}\text { Earlier Cost Auditing Standards } \\
\text { were not mandatory, but } \\
\text { according to new act these } \\
\text { standards are mandatory. }\end{array}$ \\
\hline 15. Class Action Suits. & $\begin{array}{l}\text { This concept was not there in } \\
\text { companies' act } 1956 \text {. }\end{array}$ & $\begin{array}{l}\text { Now the provision of class } \\
\text { action suit is introduced, it } \\
\text { provided that if class of }\end{array}$ & $\begin{array}{l}\text { This will bring greater and } \\
\text { efficient judicial proceedings. } \\
\text { But this section shall not apply }\end{array}$ \\
\hline
\end{tabular}

\footnotetext{
${ }^{9}$ Section 68 of the Companies Act, 2013

${ }^{10}$ Section 58A of the Companies Act, 1956

${ }^{11}$ Section 73 of the Companies Act, 2013.

${ }^{12}$ Section 171 and 172 of the Companies Act, 1956.

${ }^{13}$ Section 101 of the Companies Act, 2013.

${ }^{14}$ Section193, 194,195,197 of the Companies Act, 1956

${ }^{15}$ Section: 118 of the Companies Act, 2013

${ }^{16}$ Section: 224 and Section 619 of the Companies Act, 1956.

${ }^{17}$ Section: 139 of the Companies Act, 2013.

${ }^{18}$ Section: 135 of the Companies Act, 2013.

${ }^{19}$ Section: 117,117A, 117B, 117C, 118,119,122 of the Companies Act, 1956.

${ }^{20}$ Section: 71 of the Companies Act, 2013.

${ }^{21}$ Section: 233B of the Companies Act, 1956

${ }^{22}$ Section: 148 of the Companies Act, 2013.
} 
Analyzing Companies Act: A move towards better Governance.

\begin{tabular}{|c|c|c|c|}
\hline & & $\begin{array}{l}\text { members, depositors, or any } \\
\text { class of them conduct the } \\
\text { business in any manner which } \\
\text { are prejudicial to the interest of } \\
\text { the company or its member file } \\
\text { an application before the } \\
\text { tribunal on behalf of the } \\
\text { company or its members. }\end{array}$ & to Banking Companies. \\
\hline 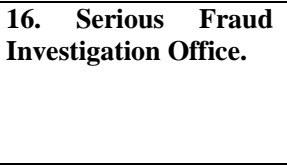 & $\begin{array}{l}\text { This concept was not there in } \\
\text { companies' act } 1956 \text {. }\end{array}$ & $\begin{array}{l}\text { As per new act central } \\
\text { government by notification } \\
\text { establish an office to } \\
\text { investigate the frauds relating } \\
\text { to a company. }\end{array}$ & $\begin{array}{l}\text { It provide transparent and } \\
\text { efficient proceedings against } \\
\text { frauds. }\end{array}$ \\
\hline $\begin{array}{l}\text { 17. Types of } \\
\text { companies. }\end{array}$ & $\begin{array}{l}\text { Private Companies, Public } \\
\text { Companies. }\end{array}$ & $\begin{array}{l}\text { Private Companies, } \\
\text { Compablic } \\
\text { Company. }\end{array}$ & $\begin{array}{l}\begin{array}{l}\text { Introduction of one } \\
\text { concept will bring } \\
\text { companies. }\end{array} \\
\text { core }\end{array}$ \\
\hline $\begin{array}{l}\text { 18. Maximum no of } \\
\text { members for private } \\
\text { companies. }\end{array}$ & $\begin{array}{l}\text { Earlier maximum number of } \\
\text { members was } 50 \text {. }\end{array}$ & $\begin{array}{l}\text { Now the members strength } \\
\text { exceed to } 200 .\end{array}$ & $\begin{array}{l}\text { This will increase the } \\
\text { requirement of number of } \\
\text { members to form a private } \\
\text { company. }\end{array}$ \\
\hline $\begin{array}{l}\text { 19. Commencement of } \\
\text { Business }\end{array}$ & $\begin{array}{l}\text { This provision of companies' } \\
\text { act } 1956 \text { is applicable to only } \\
\text { public limited companies. }\end{array}$ & $\begin{array}{l}\text { Now as per new act this } \\
\text { provision is applicable to all } \\
\text { the companies. }\end{array}$ & $\begin{array}{l}\text { Now every company is required } \\
\text { to obtain certificate of } \\
\text { commencement of business. }\end{array}$ \\
\hline $\begin{array}{l}\text { 20. Memorandum of } \\
\text { Association "Object } \\
\text { Clause" }\end{array}$ & $\begin{array}{l}\text { The object clause is divided } \\
\text { into different parts main } \\
\text { objects, incidental and other } \\
\text { objects. }\end{array}$ & $\begin{array}{l}\text { Now the MOA contains the } \\
\text { object for which the company } \\
\text { is incorporated. }\end{array}$ & $\begin{array}{l}\text { The earlier bifurcation is } \\
\text { omitted now. }\end{array}$ \\
\hline $\begin{array}{l}\text { 21. First Board } \\
\text { Meeting }\end{array}$ & $\begin{array}{l}\text { In companies act } 1956 \text { no } \\
\text { specific time is mentioned for } \\
\text { holding first meeting. }\end{array}$ & $\begin{array}{l}\text { Now every company shall hold } \\
\text { its first board meeting within } \\
\text { period of thirty days from } \\
\text { incorporation. }\end{array}$ & $\begin{array}{l}\text { This new amended provision } \\
\text { will help the directors to } \\
\text { understand the agenda of the } \\
\text { company at an early stage. }\end{array}$ \\
\hline $\begin{array}{l}\text { 22. Notice of Board } \\
\text { meeting }\end{array}$ & $\begin{array}{l}\text { In this act no specific time } \\
\text { period of notice is mentioned. }\end{array}$ & $\begin{array}{l}\text { In this act seven days notice is } \\
\text { required to call board meeting. }\end{array}$ & $\begin{array}{l}\text { The notice will reach within } \\
\text { stipulated time to every member } \\
\text { eligible for notice. }\end{array}$ \\
\hline $\begin{array}{l}\text { 23. Penalty with } \\
\text { regard to notice of } \\
\text { board meeting. }\end{array}$ & $\begin{array}{l}\text { If an officer fails to give } \\
\text { notice shall be punishable } \\
\text { with fine which may extend } \\
\text { to } 1000 \text { rupees. }\end{array}$ & $\begin{array}{l}\text { Now as per new act if an } \\
\text { officer fails to give notice then } \\
\text { he shall be liable to a fine of } \\
25000 \text { rupees. }\end{array}$ & $\begin{array}{l}\text { This will help in better } \\
\text { management. }\end{array}$ \\
\hline $\begin{array}{l}\text { 24. Maximum number } \\
\text { of directors. }\end{array}$ & $\begin{array}{l}\text { As per this act the limit is } 12 \text {. } \\
\text { More can be appointed by the } \\
\text { approval of central } \\
\text { government. }\end{array}$ & $\begin{array}{l}\text { Now the limit is } 15 \text {, more can } \\
\text { be appointed by passing special } \\
\text { resolution in meeting. }\end{array}$ & $\begin{array}{l}\text { Now the approval of central } \\
\text { government is not required. }\end{array}$ \\
\hline 25. Directorship. & $\begin{array}{l}\text { As per old act the maximum } \\
\text { number of directorship is } 15 \text {. }\end{array}$ & $\begin{array}{l}\text { As per new act the maximum } \\
\text { number of directorship is } 20 \\
\text { out of which } 10 \text { can be public } \\
\text { companies. }\end{array}$ & $\begin{array}{l}\text { The new act also includes } \\
\text { alternate directorship but earlier } \\
\text { alternate directorship was not } \\
\text { included. }\end{array}$ \\
\hline 26. Women Director. & $\begin{array}{l}\text { No women director was } \\
\text { mandatory earlier. }\end{array}$ & $\begin{array}{l}\text { Now at least one women } \\
\text { director is compulsory in every } \\
\text { board. }\end{array}$ & $\begin{array}{l}\text { Increase the role of women in } \\
\text { corporate. }\end{array}$ \\
\hline $\begin{array}{l}\text { 27. Resignation of } \\
\text { Director. }\end{array}$ & No specific provision. & $\begin{array}{l}\text { As per new act director shall } \\
\text { send a copy of resignation } \\
\text { within } 30 \text { days to ROC. }\end{array}$ & $\begin{array}{l}\text { It will give more transparency } \\
\text { about the board. }\end{array}$ \\
\hline $\begin{array}{l}\text { 28. Registration of } \\
\text { pledge. }\end{array}$ & $\begin{array}{l}\text { Earlier pledge of movable } \\
\text { property does not require } \\
\text { registration with ROC. }\end{array}$ & $\begin{array}{l}\text { As per new act, now the } \\
\text { registration regarding the same } \\
\text { is compulsory. }\end{array}$ & $\begin{array}{l}\text { This will help the public to } \\
\text { track the records of the } \\
\text { company regarding all the } \\
\text { charges, registration and there } \\
\text { pledge. }\end{array}$ \\
\hline $\begin{array}{l}\text { 29. Holding first } \\
\text { AGM. }\end{array}$ & $\begin{array}{l}\text { As per old act, maximum } \\
\text { time limit for holding of first } \\
\text { AGM is } 18 \text { months from } \\
\text { incorporation or } 9 \text { months } \\
\text { from closure of accounts } \\
\text { whichever is earlier. }\end{array}$ & $\begin{array}{l}\text { As per new act, the maximum } \\
\text { time limit is } 9 \text { months from } \\
\text { closure of accounts. }\end{array}$ & $\begin{array}{l}\text { The earlier provision of } 18 \\
\text { months has been omitted now. }\end{array}$ \\
\hline
\end{tabular}

${ }^{23}$ Section: 245 of the Companies Act, 2013.

${ }^{24}$ Section: 211 of the Companies Act, 2013. 


\begin{tabular}{|c|c|c|c|}
\hline $\begin{array}{lrr}30 . \quad \text { Consent } & \text { for } \\
\text { shorter notice } & \text { with } \\
\text { regard to AGM. } & \end{array}$ & $\begin{array}{l}\text { As per earlier act consent for } \\
\text { shorter notice was given by } \\
\text { all the members entitled to } \\
\text { vote at the meeting. }\end{array}$ & $\begin{array}{l}\text { Now the consent is to be given } \\
\text { by not less than } 95 \% \text { of the } \\
\text { members entitled to vote at the } \\
\text { meeting. }\end{array}$ & $\begin{array}{l}\text { Now the consent require only } \\
95 \% \text { voting of all the members. }\end{array}$ \\
\hline 31. Financial Year. & $\begin{array}{l}\text { Earlier companies were } \\
\text { allowed to choose freely its } \\
\text { financial year, however it } \\
\text { cannot exceed } 15 \text { months. }\end{array}$ & $\begin{array}{l}\text { Now the financial year shall be } \\
\text { from April } 1^{\text {st }} \text { to March } 31^{\text {st }} \text { for } \\
\text { all companies. }\end{array}$ & It will bring uniformity. \\
\hline $\begin{array}{l}\text { 32. Key Managerial } \\
\text { Personnel. } \\
\end{array}$ & $\begin{array}{l}\text { Earlier KMP does not include } \\
\text { Company Secretary. }\end{array}$ & $\begin{array}{l}\text { Now the KMP includes the } \\
\text { Company Secretary also. }\end{array}$ & $\begin{array}{l}\text { The role of Company Secretary } \\
\text { has broadened. }\end{array}$ \\
\hline 33. Takeover offer. & $\begin{array}{l}\text { Earlier scheme of } \\
\text { compromise and arrangement } \\
\text { does not include takeover } \\
\text { offer. }\end{array}$ & $\begin{array}{l}\text { Now the scheme of } \\
\text { compromise and arrangement } \\
\text { includes takeover offer. }\end{array}$ & $\begin{array}{l}\text { This provision will work as per } \\
\text { the SEBI guidelines. }\end{array}$ \\
\hline 34. Merger & $\begin{array}{l}\text { Earlier the provision of fast } \\
\text { track merger was not there. }\end{array}$ & $\begin{array}{l}\text { Now the provision of fast track } \\
\text { merger is there between two } \\
\text { companies. }\end{array}$ & $\begin{array}{l}\text { It will help the two companies } \\
\text { to put forward their steps } \\
\text { towards their goal at earliest. }\end{array}$ \\
\hline $\begin{array}{l}\text { 35.Secretarial Audit } \\
\text { for Bigger Companies }\end{array}$ & $\begin{array}{l}\text { Earlier this section was not } \\
\text { there. }\end{array}$ & $\begin{array}{l}\text { Now every listed company and } \\
\text { company of other classes is } \\
\text { required to comply with } \\
\text { secretarial audit report to be } \\
\text { furnished by Company } \\
\text { Secretary in practice. }\end{array}$ & $\begin{array}{l}\text { This will give better } \\
\text { governance. }\end{array}$ \\
\hline $\begin{array}{l}\text { 36. Functions of } \\
\text { Company Secretary. }\end{array}$ & $\begin{array}{l}\text { No provision was there in old } \\
\text { act. }\end{array}$ & $\begin{array}{l}\text { New act gives the clear picture } \\
\text { of functions of Company } \\
\text { secretary. }{ }^{26}\end{array}$ & $\begin{array}{l}\text { Clear the role of Company } \\
\text { Secretary. }\end{array}$ \\
\hline $\begin{array}{l}\text { 37. Committees of } \\
\text { Creditors. }\end{array}$ & No provision was there. & $\begin{array}{l}\text { Now the committee of creditors } \\
\text { is appointed by interim } \\
\text { administrator. }\end{array}$ & $\begin{array}{l}\text { This will help to save the } \\
\text { interest of various creditors. }\end{array}$ \\
\hline $\begin{array}{ll}38 . & \text { Associate } \\
\text { Company } & \\
\end{array}$ & No Provision was there. & $\begin{array}{l}\text { Now the concept of associate } \\
\text { company is introduced. }{ }^{28}\end{array}$ & It is not a subsidiary company. \\
\hline $\begin{array}{l}\text { 39. Declaration of } \\
\text { dividend in case of in } \\
\text { adequate profits. }\end{array}$ & $\begin{array}{l}\text { As per the provision of this } \\
\text { act the company can declare } \\
\text { dividend in case of adequate } \\
\text { profits out of the reserves } \\
\text { subject to the fulfillment of } \\
\text { certain rules. }\end{array}$ & $\begin{array}{l}\text { As per new act in this case } \\
\text { company can declare dividends } \\
\text { out of its accumulated profits } \\
\text { transferred to reserves. }\end{array}$ & $\begin{array}{l}\text { Earlier the maximum rate of } \\
\text { dividend was } 10 \% \text {. }\end{array}$ \\
\hline 40. Special Courts. & No provision was there. & $\begin{array}{l}\text { For speedy results for offences } \\
\text { the concept of special courts } \\
\text { has been introduced in new } \\
\text { act. }^{29}\end{array}$ & $\begin{array}{l}\text { Timely and efficient judicial } \\
\text { proceedings. }\end{array}$ \\
\hline
\end{tabular}

\section{Conclusions}

On a concluding note we can say that as time passes \& corporate sector becomes more \& more integrated with the society there is need to incorporate necessary changes in corporate laws governing this sector $\&$ the companies. No doubt the introduction of a very comprehensive Companies Act, 2013 is a milestone but the concern is about its implementation. No act is helpful if it is not implemented in its spirit; similarly there is also a need to have unified laws for corporate sectors to remove ambiguities due the existence of multiple acts \& statutes. Companies Act, 2013 overcomes some of the major loopholes of Companies Act, 1956 but there might be some loopholes with companies Act 2013 as well specially when in the areas where it does not provide for punitive or penal actions like in the case of Section 135. So there is a need to have a re look at some of the parts of the newly introduced Act.

\section{References}

\section{Books}

[1]. Sharma JP (2014), "Governance, Ethics and Social Responsibility of Business" Ane Books Pvt. Ltd. New Delhi, India.

[2]. Sharma JP (2012), "An easy approach to Corporate Laws" Ane Books Pvt. Ltd. New Delhi, India.

[3]. Kuchhal MC (2009), "Corporate Laws" Shree Mahavir Book Depot (Publishers), New Delhi, India.

[4]. Kuchhal MC (2013), "Modern Indian Company Law” Shree Mahavir Book Depot (Publishers), New Delhi, India.

\footnotetext{
${ }^{25}$ Section: 204 of the Companies Act, 2013.

26 Section: 205 of the Companies Act, 2013.

${ }^{27}$ Section: 257 of the Companies Act, 2013.

${ }^{28}$ Section: 2(6) of the Companies Act, 2013.

${ }^{29}$ Section: 435 of the Companies Act, 2013.
} 


\section{Bare Acts}

[5]. Companies Act, 1956

[6]. Companies Act, 2013

\section{Websites}

[7]. http://www.caclubindia.com

http://www.caclubindia.com/articles/comparison-between-old-versus-new-provisions-of-companies-act-

18151.asp\#.U1oBw1WSxv4 http://www.club4ca.com/formats/corporate-law/companies-act-2013-vs-companies-act-1956/

[8]. http://www.sngpartners.in http://www.sngpartners.in/files/Company\%20Law,\%20a\%20Comparision.pdf

[9]. https://www.pwc.in

https://www.pwc.in/en_IN/in/assets/pdfs/publications/2013/companies-act-2013-Key-highlights-and-analysis.pdf

[10]. http://www.kpmg.com

http://www.kpmg.com/IN/en/Documents/KPMG_Companies_Act_2013.pdf

[11]. http://www.mca.gov.in

http://www.mca.gov.in/Ministry/pdf/ProvisionsTable_CompAct.pdf

[12]. http://www.citehr.com

http://www.citehr.com/472546-difference-between-companies-act-1956-2013-a.html

[13]. http://lawsofindiaforcommanman.blogspot.in

http://lawsofindiaforcommanman.blogspot.in/2013/09/change-in-authorized-capital-comparison.html

[14]. http://www.companiesact.in

[15]. https://www.icsi.edu

https://www.icsi.edu/WebModules/LinksOfWeeks/OCT2013.pdf 